\title{
RELIGIOUS CONFLICTS MANAGEMENT BASED ON LOCAL WISDOM IN THE TEMPLE VILLAGE OF MALANG INDONESIA
}

\author{
Munirul A6idin \\ UIN Maulana Malik Ibrahim Malang \\ Email: munirula0472@gmail.com
}

\begin{abstract}
Indonesia is a country prone to conflict, because it has a pluralistic, multi-ethnic, multi-religious and multi-cultural society. Therefore, it must be certain efforts to prevent the conflict between them in the community. This research aims to describe the conflict resolution through values of local wisdom. It employs qualitative approach with observation, interview, and documentation as methods to collect data. The finding shows that local wisdom values have big contribution to make community with complex religions and ethnic lived in harmony. Local wisdom values also have big role to resolve all conflict problems in the community and make them more humble, tolerant and wise to face the problem in their lives.

Indonesia merupakan negara yang rawan terjadi konflik. Salah satu penyebabnya adalah karena Indonesia negara yang memiliki masyarakat majemuk, multi etnis, multi agama dan multi budaya. Karena itu, harus ada upaya-upaya tertentu agar konflik antar etnis, agama dan budaya tersebut tidak terjadi dalam masyarakat. Penelitian ini bertujuan untuk mendeskripsikan managemen konflik berbasis nilainilai budaya lokal. Penelitian dilakukan dengan pendekatan kualitatif. Metode yang digunakan untuk mengumpulkan data adalah pengamatan, wawancara dan dokumentasi. Penelitian ini menemukan bahwa nilai-nilai budaya lokal memiliki kontribusi yang besar untuk menciptakan masyarakat yang memiliki kompleksitas agama dan suku hidup dalam suasana yang harmonis. Nilai-nilai budaya lokal juga memiliki peran penting dalam memecahkan masalah konflik dalam masyarakat, serta menjadikan mereka lebih ramah, toleran dan bijaksana dalam menghadapi problem-problem kehidupan.
\end{abstract}

Keywords: religious conflict, management conflict, local wisdom 


\section{Introduction}

These days, conflicts caused by religious and ethnic differences have occurred in some places in Indonesia. There had been ten examples of conflict in Indonesia, like conflicts that happen in Poso, Solo, Ambon, Madura and Sambas ten years ago which become the witness of it (Rahman, 2013: 13). The factors that cause those religious conflict are social and territorial aspects, outsider factors and betrayed heart, religious leaders and scriptural reading (Epafras, 2007: 56). Social and territorial aspects become an important cause while the religion factor binds together a social unit. When the community bound is relatively strong, it is easy to be provoked to conflict when their social bound is injured.

In a pluralistic society, usually every community has its own values that bind them. However, these values are not binding for other communities. As a result, when the values of certain groups of people are violated by other people, it is considered to hurt or belittle the people who uphold these values. Therefore, some religious and racial conflicts that occurred in several regions outside Java, as mentioned above, most occur in areas that have strong social bounds within a particular group, whether they are bound by religious values or regional values (ethnic), but the values are not binding for other communities in general.

Temple community has different characteristics to what is described above. Although they consist of many religions and ethnic groups, they can coexist harmoniously. The questions are why they can live in harmony in diversity, what values they gather in unity are and how they manage conflicts in their communities. This research becomes important to serve as a model for conflict resolution in a pluralistic society vulnerable in Indonesia.

\section{Theoretical Perspective of Conflict}

Conflict is a common phenomenon in our life, although the view of conflict itself is different. Some people see conflict as something negative that should be avoided whenever possible. Others view conflict as a normal phenomenon that requires management and a valuable opportunity for someone to improve his personality so that he can take great benefit from it (Fleetwood, 1987: 1).

Conflicts can occur anywhere and at any time, in various fields, social, politics or religion. Where there are two or more social communities such as individuals, groups or organizations that are interconnected with others with 
different goals and interests, there will be a conflict (Rahim, 2001: 1) as the conflict is caused of different perception of society (Thompson, 1998: 4).

From the perspective of sociology, the study of social conflict has gained attention since the publication of the works of Mayo (1933) and Parsons (1949). Mayo who focuses on the development of human relationships asserted that creating an effective organization of community life needs cooperation. Conflict was a "demon" that should be avoided, even if possible eliminated from all forms of organization (Mayo, 1933).

In line with Mayo, Parsons formulated the structural-functional theory which assumes that basically people live in a stable, unified and functional state (Parsons, 1949: 12-15). Therefore, the conflict is seen as an abnormal condition and dysfunction (Litterer, 1966: 178).

At a later stage, the conflict is no longer seen as something negative, but it has positive values to build a society. A number of theories that oppose the views of Mayo and Parsons began to appear, such as the theory of Mills (1959), Dahrendorf (1950), Bernard (1957) Coser (1956) and so on. Coser (1956) for example, published the functions of social conflict illustrating that the conflict has considerable benefits for the development of society itself. Therefore the study of the conflict continues, both in the social, political, religious and other organizations.

Conflict is classified into four, namely (1) intrapersonal conflict, (2) interpersonal conflict, (3) intragroup conflict and (4) intergroup conflict. Judging from the source, the conflict is divided into ten, namely (1) the affective conflict, (2) substantive conflict, (3) conflict of interest (interest), (4) a conflict of values, (5) the purpose of conflict, (6) realistic conflict against nonrealistis , (7) conflict against nonlembaga institutions, (8) conflict retributive, (9) misatribut conflict, and (10) displaced conflict (Rahim, 2001: 21-24).

Likewise, inter-religious conflicts can occur due to many factors. The religious conflict are caused by four main factors: (1) differences in doctrine and mental attitude, (2) differences in ethnicity and race religions, (3) differences in the level of culture, and (4) the majority and minority religious groups (Hendropuspito, 1983: 151-168).

Meanwhile, the conflict between ethnic and religious communities are caused by two factors, the macro and micro factors. At the macro level, the cause of religious conflict is (1) dissatisfaction among religious groups in the control of assets and employment, (2) unmanaged community to open and seek solutions together, (3) weak in the analysis of external provocation. While 
the cause of the conflict between religious communities in micro is (1) cultural differences, (2) unbalanced competition, (3) thuggery and crime, (4) centralized government policies, (5) socio-economic competition unbalanced and (6) the powerlessness of law enforcement officers (Malihah, 2002: 16-18).

To resolve inter-religious conflict, conflict management is required. It may involve two models of conflict resolution, namely cooperative and competitive models (Deutsch, 1949: 129-152). Other theory proposes three models of conflict resolution, non-confrontation, integration and domination models (Putnam $\&$ Wilson, 1982: 629-652). The model can also be divided into four models; to give up, resolve the problems, slowed, and compete (Pruitt, 1983: 167-194). While, Blake and Mouton divide the model into five; to attack, withdraw, be subtle, compromise and resolve the problem (Blake \& Mouton, 1964: 78-79). Rahim also proposes five models of conflict resolution; domination, integration, support, dodge and compromise (Rahim, 1979: 44).

Basically, conflict management requires a high level of communication, especially if the conflict involves a cross-cultural setting. Ethical values is needed in order to obtain a good solution to the conflict and in accordance with local circumstances. Among these values are the values of local wisdom (Rahim, 2001: 183-185).

Local wisdom is the way and practices developed by a group of people from their deep understanding of the local environment formed in place for generations. Local wisdom is distributed non-formally, owned collectively by the people concerned, developed over several generations and easily adapted and embedded in the way of life of the community as a means to survive. The properties of local wisdom are (1) have the ability to revitalize, (2) has a sustainable nature, (3) can adapt to a new culture that does not conflict with local values (Dimyati, 2011: 14)

With characteristics as mentioned above, local cultural values can be applied as a means to resolve social conflicts, the impact of natural disasters, as well as the development of cultivating culture in the spirit of improving the quality and superior product based on local area (Dimyati, 2011). Fitri's study describes the pattern of a harmonious interaction between myths, sacred and cultural wisdom in Pasuruan society. The values of local wisdom is able to adapt with the myths and sacred values developed in the society (Fitri, 2012: 1-15). While, Widhiya illustrates that local knowledge has a very big role in resolving conflicts in Lampung (Widhiya, 2012: 97-110). 
By some of the views above, this paper aimed to see how far the values of the local culture (wisdom) contribute to resolve the problem of social and religious conflicts in Temple Village Malang Indonesia. It is expected to enrich the discourse of cultural local wisdom and its role in resolving conflicts in society.

\section{Research Methods}

This study used a qualitative approach with case study design. The data were collected through three data collection techniques; depth interviews, observation, and assessment documents. Interviews were conducted with informants, using open-ended and unstructured question. The data obtained are information about the community's efforts to avoid conflict in Temple Village. Observations were carried out to obtain data on the intensity of the village officials and all the people associated with the research object . Transcript of the interview and observation is confirmed by the subject. Assessment on documents is done to add the information obtained from interviews and observations. Documents are reviewed on the explicit goal, the program or plan that has been drawn up, the implementation of the program, and the proof of the results that have been achieved. These are taken from the reports as one of the formal indicators of the management pattern of avoiding conflict in the society. The review on the documents is also conducted to obtain information about the number of residents, both in quantity and quality, as well as the number of ethnic and religious differences.

To obtain pure data about the phenomenon under study, as a key instrument of data collection, the researcher conducted a phenomenological reduction, eidetis reduction, and transcendental reduction (Dimyati, 1997: 78). Phenomenological reduction is done by freeing from a subjective assessment of the phenomenon studied, so that the pure data is collected from the phenomenon, not the subjective opinion of the researcher. Eidetis reduction is conducted by freeing himself from the theory, scientific propositions or traditional doctrine that could contaminate the purity of the data. In the transcendental reduction, the researcher looked at the nature of the phenomenon of the conflict management performed by the residents of Temple Village.

The process of data analysis was conducted in multiple stages which include 1) the analysis of case data that starts at the time of data collection which consists of; a) checking, b) organizing, and c) coding. 2) analysis of data after the data are collected as a whole which includes; a) meaning, b) interpreting, and c) drawing conclusion (Yin, 1984: 84). 


\section{A Glimpse of Temple Village}

Temple Village has a diverse population, multi-ethnic and religious. Its population consists of several ethnic, mostly are Javanese and Madurese. In addition, there are other ethnic groups from eastern Indonesia, such as Ambon, Maluku and Irian Jaya. Although most of them do not become permanent residents, but their presence in the village is quite a lot, because they have a relationship of cooperation with several universities, especially the National Institute of Technology (ITN) and the College of Communication Studies (STIKI). They live in houses and in certain events, they come to blend with the surrounding community.

The Temple Village also has diverse religious communities. Most of them are Muslim, while others are Catholic, Protestant, Hindu and Buddhist. Historically, a native of the Village Temple is a Hindu and Buddhist. It can be seen from some historical relics that still exist, such as the presence of several Temples that stood around the Village Temple. One of the Temples that still exist and serve as tourist attractions is a Temple of worship for followers located in the Badut Village. It is said that once around the Village Temple there are other Temples which are not maintained and the devotees have died so that eventually those Temples become extinct. Accordingly the street around the Village Temple is called the Temple street.

After Islam came to the village Temple, which was brought by the preachers, Hindus and Buddhists gradually reduced. However, some traditions are still survived until now, even though they are no longer embraced Hinduism and Buddhism.

In addition to the Muslim, Hindu and Buddhist, there also many peoples who embraced Christianity, especially Catholicism. Actually, the Village Temple once a target village of Christianization. Therefore, in this village there are many established seminaries, the institution of the priests, pastors, zending and nuns. In this village, there are three seminaries and Christian schools.

Although the community in Temple Village is diverse in ethnicity and religion, the atmosphere of their daily lives remain harmonious. There is no conflict between them, despite the differences in ethnic and religion. They live in harmony, peace and mutual good relations with each other. Such harmony is not only visible in everyday life, but also in the atmosphere of the great days of Islamic, Hindu or Christian celebration. At the time of Muslim celebration for example, the majority of Christians in this village also visit the Muslim to congratulate them. They also made a large banner displayed 
at the roadside congratulated the Muslim community. Vice versa, during Christian celebration such as Christmas, some Muslims came to the homes of Christians to congratulate. At that time the Seminary also contributed goats to the community, to be slaughtered and distributed to the surrounding community.

Harmonious atmosphere is also visible at the time of the celebration of national days like the celebration of Indonesian independence day on 17th August. All citizens participate enliven the independence day in various forms of activities, such as contests, village carnival, parade, and so on. At that time, all the elements of society, both from the boarding schools, seminaries and the people joined the activity. Although they are of different religions and ethnic groups, they did not make the difference. They are soluble in unity and in an activity celebrating the anniversary of the Indonesian nation.

\section{Local Culture Adhesives Between Religious Communities}

There are some local cultural activities in the Village Temple which can be inter-religious adhesive media. Such activities are Slametan Deso (cleaning the village ceremonial), Bantengan, Gonggongan and Paguyuban.

Slametan deso or cleaning the village ceremonial is an annual event that is believed to be the anniversary of the village Temple. On that day, all residents clean up the environment respectively, from the gutter to public places. After that all communities gathering in the village halls by bringing cone, fruits or other snack. The event began with speeches, ranging from the head of village and then continued with prayer. Prayer is usually led by the village elders who usually still adhered kejawen clans, known as abangan. The prayer called ojob usually use the ancient Javanese language, which is different from the Java language that is used for daily communication.

Nevertheless, the existence of this ojob figure is taken into account in the community and every resident who held a big celebration, such as wedding party, circumcision and so on, they always call the ojob prayer to open the event. After the ojob prayer, followed by a prayer representatives of religious groups, which are usually represented by a local clerics or religious teacher from Islam or Christian. But at a later time, as the village community dominated by the santri, the tradition of prayer together, especially those presenting other religious leaders to participate in activities that lead prayers, began to disappear. However, it does not cause conflict, because they are aware of the number of minorities. After the whole procession is completed, the program 
ended with a bite to eat together at a place and if there is the rest of them, they can bring it back to their homes.

Bantengan is a typical Malang culture that has been a tradition for generations. In Bantengan people usually make a bull's head made of wood as a medium for dancing. In addition to the bull's head, it is usually also equipped with other figures, such as dragons or Buto (giant) as his opponent. Until now Bantengan tradition is still alive in every corner of the lively town and village in Malang, including in the village Temple. Almost in every village activities or the national celebration, people always present Bantengan to entertain the public. Indeed, in general, people are happy with Bantengan as abangan's activities, but many are also santri and those Christians who get involved in the activities of Bantengan. There are even some Chinese people who joined Bantengan, so occasionally they combine it with a lion dance. In this Bantengan tradition, all elements of society can be merged into one, regardless of group, religion or race, as the glue between groups and religious communities.

Gonggongan is gamelan percussion that is used to accompany Javanese song. In this tradition, the gap between abangans, Hindu, Buddhist and Islam becomes liquid. Even the head of Village Temple, formerly Hindu and the whole family is Hindu. After marrying a Muslim girl he eventually converted to Islam. But in the tradition of gonggongan, though not Muslims, they are also accustomed to sing the Islamic Javanese song, like Tombo ati, Lir ilir and so on.

Paguyuban is the village routine activities carried out every month to collect all the villagers, regardless of differences in race, language and nation, to discuss issues related to joint problems, such as the cleanliness of the village, road improvements, public services, community activities. Paguyuban was held in the homes of residents in turns, ranging from the neighborhood level to the village level. In Paguyuban, usually not discussed religious matters, but merely an common community activities. To support the activities of the Paguyuban, usually they held regular social gathering. People who get a lot at that time, will host the next month. In this community all the villagers could meet, regardless of ethnicity and religion, so that all problems can be resolved and in turn the harmony of life between people can be well preserved. 


\section{Forms and Causes of Conflict}

Although in the daily life of the Temple society looks harmony, but sometimes there are some factors that cause conflicts in society, although the conflict does not make society of Temple divided. Among the forms of conflict ever arises in Village Temple are as follows:

\section{General Election of Village Head}

General election, ranging from the village head election till President election often cause conflict between people in Temple Village, both Muslims or non-Muslims community. On October 12th, 2012, there were village head election. Preceding the election, the committee selected candidates through a questionnaire. The committee finally determined the three candidates of village head who represent specific groups. One candidate represented a group of santri (muslim), another represented the nationalist-abangan and the other one represented the non-Muslim groups. A few days before the election, some issues arisen by religious group warning the people not let the head of village controlled by non-Muslims, because it will facilitate the permit process of church establishment in the Temple Village. These issues seemed to be able to gather the vote of a group of santri in the Temple Village, so that the Muslim group won in 2012.

\section{Funeral Muslims and Non-Muslims}

In Tempel village there are five common burial place. However there is a conflict that continues until now in burying the bodies of non-Muslims in general cemetery. Most local residents refuse non-Muslims bodies in the general cemetery, because the owners were donating their land for the cemetery only for Muslim bodies. Therefore, if there are non-Muslim citizens Temple, who died, usually taken to another village or other public burial sites that accept non-Muslim citizens. Based on this conditions, the village head took a new policy. Since the 2000s, some of the lands in Temple Village have been used as public burial place for all residents regardless their religions or tribes. With the policy, the funeral problem of non-Muslim can be overcome.

\section{Establishment of the new Worship Houses}

Another conflict occurred in Temple Village is associated with the establishment of new places of worship, especially the establishment of church. In 2005, there are rumors that a new church will be built in Temple Village. 
At first the housing developers freed the land from residents only for housing, not the church. But lately, because the majority of land buyers are Christian, they would build a church. Hearing the news, the land owners who sell their land to developers were angry and many of them canceled the sale. Leaders of religious groups consulted in order to prevent the establishment of the church, arguing that Christian population is not sufficient to build a church. Although they are many Christian, but they are from several streams. After a long process finally the village head decided that the establishment of a new church must obtain permission from the local community and government.

\section{The Values Of The Local Wisdom That Prevent Conflict}

Temple Village community have noble values that have been passed down from generation to generation. These values are often promoted at community meeting that involve all residents. Among these values are:

(1) Guyup Rukun dan Ewuh pakewuh (living in harmony and keeping each other).

This value taught that all people must live in harmony with their neighbors and the entire village community. Togetherness and harmony are the values that must always be adhered to ensure that people can live in peace. In case a conflict occurs with neighbors or community they would feel uncomfortable with it or with the public, because it will ruin the harmony of life and undermine solidarity they have built.

(2) Aluwung ngalah timbang nyalah (to succumb is better than to blame others)

This value implies that they don't like to have clash with others. In case of dispute, they prefer to make peace or succumb rather than blaming others. In this way commotion or fighting among people, either of the same or a different religion is very rare. If the conflict occurred, they will be easily reconciled because they hold the same value.

(3) Nglurug tanpo bolo, menang tanpo ngasorake (attack without troops and win without degrading).

This value implies high sportsmanship. For the people of Temple Village, if they have a problem with one of the residents, they will finish with a non-violent manner. If the problem can be solved in a good way, it does not need to be done with the mob. It is also not necessary to fight, so there should be no one get humiliated or defeated. This method is used by the temple community in resolving conflicts between them. 
(4) Gotong Royong (mutual cooperation).

This value is always maintained and implemented by the temple community in all forms of social activity. Among the activities undertaken by Temple community jointly are village cleaning, keeping the security, renovating public facilities and celebrating village fest.

\section{Managing Conflict Based on Local Wisdom Values}

Inspite of the fact that temple society is complex, multi-ethnic and religion, they live in harmony. There was never a serious conflict that resulted in physical assault, destruction of places of worship or other anarchic actions as happened in some other places like Poso, Lampung, and Sumenep. This condition happens because temple people have local cultural values or local wisdom that bind the whole society, then they are more concerned with unity rather than division. Local values makes temple society more tolerant than other communities that don't have the values of local wisdom. Sumbulah's finding shows that the Javanese community in general have a higher tolerance than people in other areas. Therefore, wherever they are, there would be rare conflict with other tribes. This tolerance, according to anthropologist assessment, is not pure tolerance, but the tolerance influenced by local cultural values (Sumbulah, 2012: 66).

The majority of temple people are Muslim. However they choose Islam that can adapt to local cultural values rather than radical Islam. In Islam there is the doctrine of jihad for example, but they do not interpret jihad as an aggressive attitude to face the minority of non-Muslim community in temple. They prefer the way of peace in solving various problems that exist in accordance with local values they hold.

In resolving conflicts of both intergroup and intragroup, the society prefers to avoid conflict (Rahim, 2001: 41) or non-confrontation and integration (Putnam \& Wilson, 1982: 18). For them, conflict avoidance is better than other methods such as domination or confrontation. This phenomenon occurs because they have been influenced by local cultural values that they hold together, such as "Aluwung ngalah timbang nyalah (to succumb is better than to blame others) and Guyup Rukun dan Ewuh pakewuh (living in harmony and keeping each other)".

The values are effective in helping the community of Temple Village in solving social problems, such as social and religious conflicts. Therefore, people live in harmony and peace despite the difference in ethnic and religion. 
These findings also accept the models proposed by Deutsch, namely the two models of conflict resolution; cooperative and competitive models (Deutsch: 1949: 129-152). Of the two models, the conflict resolution in Temple Village is more cooperative than competitive. Although in some cases, as in the case of conflict on burial of non-Muslim communities tend to be tough, the communal cooperation in resolving the conflict remains clearly visible. It is mediated by the village government to find a solution that is acceptable to all communities. These values were also found by Mufidah in the event and the tradition of the santri in the Abangan village at Sumberpucung Malang (Mufidah, 2012: 115-130).

For the people of temple, the conflict does not only have a negative impact, but also bring the society to be mature, productive and harmonious. Settlement of Muslims and non-Muslims tomb for example, has made society more mature, because the solution to the problems can satisfy all parties. As said by Kelly and Kelly (1998) the conflict has positive benefits for the community. Among its benefits are (1) to encourage innovation, creativity and growth, (2) to develop organizational decisions, (3) to find new alternatives of settlement problems, (5) to provide a synergistic solution to the ordinary problems, (6) to encourage people looking for a new approach, and (7) to articulate and clarify their positions among individuals and other groups.

\section{Conclusion}

For the temple community, the values of local wisdom community can be a powerful element in managing conflict. These values can serve as a melting pot of assorted differences into something complete and cohesive. Every community may have their own values, but when dealing with other communities they must abandon those ethnic or religious values and switched to the local wisdom values that can protect from these differences. Therefore, the values of the local culture becomes important to be maintained in order to unify the diverse communities to live in a harmonious society.

In managing conflict, each member of the community must be willing to sit together without promoting the values of ethnic or religious in his hand. They should be cooperative rather than competitive. Conflict management with cooperative approach means that every person in the conflict should be willing to gather and hear the reasons of the other groups that are known principally for problem solution. If they use a competitive approach in conflict resolution, then each group will try to win. Consequently, the conflict will 
become increasingly large and unresolved. Local cultural values could be a reference in the resolution of conflicts, because they realized that although they were of different race, ethnicity and religion, they are still in the same community.

\section{References}

Bernard, J. 1957. The sociological study of conflict. In International Sociological Association (Ed.), The Nature Of Conflict: Studies On The Sociological Aspects Of International Tensions. UNESCO, Tensions and Technology Series.

Blake, R.R., dan Mouton, J.S. 1964. Managing Intergroup Conflict In Industry. Houston, TX: Gulf.

Coser, L. A. 1956. The Functions Of Social Conflict. Glencoe, IL: Free Press.

Dahrendorf, R. 1959. Class And Class Conflict In Industrial Society. Stanford, CA: Stanford University Press.

Deutsch, M. 1949. A Theory of Cooperation and Competition. Human Relation, 2.

Dimyati, Ahmad. 2011. Dakwah dengan berpijak pada Kearifan Lokal Lebih Kuat dalam menghadapi Globalisasi. Dalam http://duniaglobalislam.blogspot. com/2011/05 /dakwah-dengan-berpijak-pada -kearifan.html (Diakses tanggal 06 Nopember 2012)

Epafras, Leonard. C. 2007. The Root Causes of Religious Conflict: Some Indonesian Cases. Paper Presented in International Youth Consultation on InterReligious Dialogue in Malang-Indonesia on 21-26 July, 2007. https:// www.academia.edu/2309615/The_Root_Causes_of_Religious_Conflict_ Some_Indonesian_Cases (accessed on February 8th 2015)

Fleetwood, Karen L. 1987. The Conflict Management Styles And Strategies Of Educational Managers. University of Delware.

Kelly, J., \& Kelly, L. 1998. An Existential-Systems Approach To Managing Organizations. New York: Oxford University Press.

Litterer, J.A. 1966. Conflict in organization: A re-examination. Academiy of Management Journal. 
Mahmudi, Agus Zainul. 2012. Pola Interaksi harmonis Antara Mitos, sacral dan Kearifan Lokal Masyarakat Pasuruan. Dalam Jurnal El-harakah: Jurnal Budaya Islam. Vol. 14. No.1.

Mayo, E. 1933. The Human Problems Of An Industrial Civilization. New York: Macmillan. New York: Oxford University Press

Mills, C. W. 1959. The Sociological Imagination. New York: Oxford University Press. Paris: UNESCO.

Mufidah, Ch. 2012. Perhelatan tradisi kolaboratif Kaum Abangan dengan Kaum santri Pinggiran di Desa Sumberpucung Kabupaten Malang Jawa Timur. Dalam Jurnal El-harakah: Jurnal Budaya Islam. Vol. 14. No.1.

Ninsiana, Widhiya. 2012. Pendekatan Multikultural dan Kearifan Lokal: Solusi dalam Masalah Konflik di Lampung. Dalam Akademika: Jurnal Sosial Budaya dan Pemikiran Islam. Vol. XVII. No. 01 bulan Januari-Juni. P3M STAIN Lampung.

Parsons, T. 1949. Essays In Sociological Theory: Pure And Applied. Glencoe, IL: Free Press.

Pruitt, D.G. 1983. Strategic choice in negotiation. American Behavioral scientist.

Putnam, L.L., dan Wilson, C.E. 1982. Communicatiove strategies in organizational conflict: Realibility and Validity of a measurement scale. Dalam M. Burgoon (Ed). Communication Yearbook 6. Bavery Hill, CA; Sage.

Rahim, M.A. 1979. The management of intraorganizational conflicts: A laboratory study with organization design. Management International Review.

Rahim, M.A. 2001. Management Conflict in Organization. Quarum Book. Westport Connecticut. London.

Rahman, Waldi. 2013. Sepuluh Contoh Konflik di Indonesia, (http://www. academia.edu/5627377/10_Contoh_Konflik_Di_Indonesia (diakses tanggal 05 Februari 2015).

Sumbulah, Umi. 2012. Islam Jawa dan akulturasi budaya: karakteristik, variasi 
dan ketaatan ekspresif. Dalam Jurnal El-harakah: Jurnal Budaya Islam. Vol. 14. No.1.

Thompson, L. 1998. The Mind and Heart of the Negotiator. Upper Saddle Riverm NJ. Prentice-Hall.

el Harakah Vol.16 No.2 Tahun 2014 